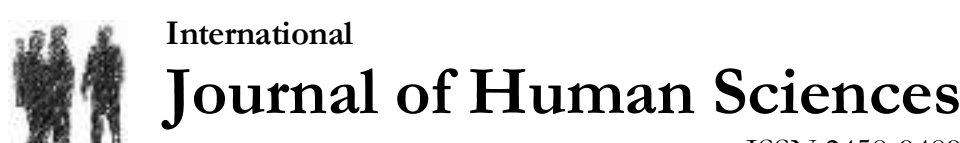 \\ ISSN:2458-9489
}

Volume 14 Issue 4 Year: 2017

\section{The relationship between mobbing and organizational cynicism: An empirical study}

\author{
Aykut Bedük ${ }^{1}$ \\ Kemalettin Eryeşil ${ }^{2}$ \\ Gülten Duran Altınışık ${ }^{3}$
}

\begin{abstract}
Today, one must pay attention to all kinds of issues held the sustainable competitive advantage of the organization to survive are mobbing and organizational cynicism. Mobbing and review of the literature on the effect of organizational commitment, cynicism and the impact on overall business performance and organizational cynicism and psychological effects of violence were found in the study of the relationship between. Hence the study "Is it cynicism triggers mobbing organizational sense?" is responding to basic research questions. In this study, mobbing him with cynicism and organizational dimensions (cognitive, emotional and behavioral) were studied to determine the relationship between and direction. The study is an empirical research quality. As data collection tool questionnaire was used. The universe of this research is composed of the faculty members and lecturers of the four vocational high schools which are affiliated to Konya Selcuk University center. The obtained results have been found suitable for factor analysis. Exploratory factor analysis was conducted to test the validity of the scale used in the study. Exploratory factor analysis obtained under Kaiser Meyer Olkin (KMO) and Barlett Sphericity Test. Cronbach's alpha coefficients of the scales were studied to examine the level of credibility of the survey. Our research has emerged reliable results. When done correlation analysis results in the overall evaluation, and said that mobbing in organizational cynicism of all sizes have a positive and statistically significant relationship at a high level $(\mathrm{r}=0,752)$.
\end{abstract}

Keywords: Mobbing; Cognitive, Emotional And Behavioral Cynicism; Organizational Cynicism.

\section{Introduction}

Mobbing is expressed as a systematic and long standing emotional oppression, applied by one or several people by becoming a gang, to an employee, who forms a threat for some people due to his/her success, knowledge, or positive attitudes. In mobbing process, person, as a result of that he/she is disturbed by his/her managers or workmates in working environment, can go toward behaviors, which will reduce the organizational efficiency, such as coming to the job late, shirking, leaving the job, and taking the long time day off and his/her organizational motivation decreases (Gül and Özcan, 2011:108). If organizations do not adequately meet the needs and expectations of their employees and do not make any effort about meeting these, this case can lead to employees to become unhappy, exhibit low performance, and enter several negative attitudes and behaviors

\footnotetext{
${ }_{1}^{1}$ Prof. Dr., Selcuk University, Faculty of Economics and Administrative Sciences, abeduk@hotmail.com ${ }^{2}$ Res. Ass., Selcuk University, Faculty of Economics and Administrative Sciences, kemalettineryesil@hotmail.com ${ }^{3}$ Ph.D. Student, Selcuk University, Faculty of Economics and Administrative Sciences, avgultenduran@hotmail.com
} 
Bedük, A., Eryeșil, K., \& Duran Altınıșık, G. (2017). The relationship between mobbing and organizational cynicism: An empirical study. Journal of Human Sciences, 14(4), 3167-3176. doi:10.14687/jhs.v14i3.4805

against their organizations. Organizational cynicism, one of the variables examined in this study, comes to our face as a concept taking place between these negative attitudes and behaviors under consideration. In this context, organizational cynicism is expressed as employees' believing that organization ignores the principles such as ethical integrity, justice, honesty, and sincerity for the sake of providing organizational utility from employees (Kahya, 2013:35). In the studies carried out, it is seen that the mobbing and organizational cynicism, which causes the attitudes containing the actions that may harm to organization and emerges as a resistance against the development of organization, lead many negative outcomes to be experienced, which may result in organization to lose its successful and talented staff, worker turnover to increase, organizational engagement and trust to decrease, absenteeism to increase, alienation, and disobedience. Therefore, it is necessary for organizations to develop the strategies of managing mobbing and organizational cynicism and lower the negative attitudes and behaviors against organizations to minimum (Ayduğan, 2012). This study aims to examine the relationship between mobbing and organizational cynicism. Due to the scarcity of similar studies carried out in this area, revealing the relationship between the variables concerned will also contribute to the theory. In this framework, in the scope of the study, firstly, some hypotheses were formed regarding the relationship between the variables considered and then the application made to test hypotheses was given place.

\section{The Conceptual Framework}

\subsection{Mobbing}

The concept "mobbing" coined by the word "mob" in English means "disorganized crowd applying force" (Mete et al., 2015:39). The word mobbing was first used by Konrad Lorenz in 1960s to define the behaviors animals' exhibit to throw away their enemies or the foreigners. Later, in 1970s, Paul Heinemann from Sweden used "bullying" another term used in this area. But, while "bullying" was used to define tyranny in school environment, mobbing was begun to be used to define the conflictions between adults in business world. In 1980s, Leyman, a clinical psychologist, dealt with the reflections of the behavior mobbing between adults and examined the phenomenon "psychological abuse" in workplaces and this concept was used to express emotional attacks in workplaces (Davenport et al., 2003:24; Göktürk and Bulut, 2012:54).

For describing this process, in which the hostile attitudes in workplaces emerge, there are many concepts. However, those used the most commonly among these concepts are the terms "mobbing" and "bullying". Leymann deliberatively used the term "mobbing" in his studies related to the subject and did not prefer the term "bullying". The foundation of distinction made by Leymann between the terms bullying and mobbing consist of psychological and physical induced violation (Rayner and Hoel, 1997:182). According to Leymann, bullying evokes physical attack, violence, and threat. Even though physical violence is very rarely met in the harming and destructing actions in workplaces, the same phenomenon is strongly characterized with physical aggression actions in schools. Therefore, Leymann suggests the term "bullying" for school organizations and the term "mobbing" for workplaces. On the other hand, in our country, although there is no consensus in the literature about Turkish meaning of the word mobbing, in the studies carried out on the subject, the concept "mobbing" is used in the meaning of "intimidation", "psychological abuse", "psychological terror", "psychological violence", "emotional abuse", "spiritual abuse", "tyrancy", and "psychological attack" in Turkish, instead of expressing it with a single word. Although there are many words for the concept mobbing in the world languages, this concept is generally used without translating into any language as mobbing (Karcioğlu and Çelik, 2012:60).

The concept mobbing is expressed in the form of that "the people more than one begin a preparation for attack against another person, coming together, and form a front against the person concerned". Leymann suggested that this form of attack he called "psychological terror" was a systematic applied process, carried out by stigmatizing the person in organization and encroaching. 
Bedük, A., Eryeșil, K., \& Duran Altınıșık, G. (2017). The relationship between mobbing and organizational cynicism: An empirical study. Joumal of Human Sciences, 14(4), 3167-3176. doi:10.14687/jhs.v14i3.4805

In this context, it will be convenient to deal with the concept mobbing as attack of an organized group come together to realize a certain aim (Leymann 1996:165). In other words, mobbing is defined as a psychological terror applied by one or several people to another person in a workplace, systematically using a hostile and unethical communication (Çetin and Bağc1 Kurt, 2014:113).

Mobbing has become a complex, multidimensional, and multidisciplinary subject, which has been experienced since the existence of working life but avoided it's releasing as a necessity of human nature, and almost ignored. Mobbing is applied in the form of attacks repeated by the other employees and employers in workplace and targets on a kind of psychological violence and intimidating employee and keeping him/her away from workplace in general (Baş and Oral, 2012:12).

In addition, mobbing includes meanings expressing behaviors such as every kind of maltreating, threat, violence, and humiliation applied systematically to the employees by their superiors, subordinates, or employees at the same level (Polat and Pakiş, 2012: 212). The studies carried out show that the people on the main target of the behavior mobbing in workplaces are the people, who challenge against the group applying mobbing, not accepting the wrong and unethical behaviors and policies of this group (Karahan and Yllmaz, 2014:5695).

Although the different definitions emerge related to mobbing, there are some main emphases and features the research agrees upon these definitions. If it is necessary to make a general definition considering the common emphases and features dealt with all of mobbing definitions, mobbing requires that there is a power unbalance between those exposed to mobbing and those applying mobbing; that negative behaviors are applied to sufferer; that these behaviors systematically continue in terms of continuity and frequency; that they happen at least once a week and continues at least 6 months; that they target on moving away, intimidating, and provoking the sufferer; and that the people applying mobbing make this behaviors deliberately and purposely (Solmuş, 2005:2; Gül and Ağı̈öz: 2011:35).

\subsection{Organizational Cynicism}

The word of cynicism has been derived from the words of "Zynismus" formerly and "Kynismus" later on. Nietzche also used cynicism as "Cynismus" in the $19^{\text {th }}$ century. In the English literature this word is used as "Cynicism" (Shea, 2009: 2).

Cynicism is an attitude to be pessimistic and explain the events based on disappointment about the secret and unreleased of the people and tendency to be interested in the other as only as an instrument and manage the businesses to keep and increase his/her own interests (Moutner, 1997:119; Tokgöz and Yllmaz, 2008:302). Andersson and Bateman (1997) called "cynic" to the person, who believes that individuals protect only their own interests and that they value their interests above, and who accepts everybody as self-seeker, and "cynicism" to the thought trying to describe this (Andersson and Bateman, 1997:450; Altınöz et al., 2011:289). Besides cynicism is defined as an individual characteristic and emotion of a person, it is defined as a negative attitude against the changing environmental factors in many studies (Anderson and Bateman, 1997:450). Just as individuals show their negative attitudes to the changes in their environments, they can also show to the organizations they work in. In this context, the concept "organizational cynicism" has also developed. Organizational cynicism is the negative attitude of the employee against the organization he/she works in (Dean et al., 1998:345). This negative attitude reveals with the formation of the belief of lack of integrity in individual against the organizations he/she works in Abraham (2000).

We can examine the elements of organizational cynicism in five sub forms as personality cynicism, social/institutional cynicism, occupational cynicism, employee cynicism, and organizational change cynicism (Arslan, 2012:15). Personality cynicism is a kind of cynicism, in which employees exhibit the negative attitudes and behaviors and is generally inherent (Fettahlioğlu, 2015:181). Social cynicism is that the citizens living in a country do not trust to the administrators of country and have emotion that their expectations in society cannot be meet (Ahmadi, 2014:27). 
Bedük, A., Eryeșil, K., \& Duran Altınıșık, G. (2017). The relationship between mobbing and organizational cynicism: An empirical study. Journal of Human Sciences, 14(4), 3167-3176. doi:10.14687/jhs.v14i3.4805

Occupational cynicism is the states of being alienated from the job, entering in carefree attitudes, and behaving insensitively (Kiliç, 2011:14). Employee cynicism includes negative states such as that employee's exhibit contemptuous attitude toward targets (Erdoğan, 2013:21). Organizational change cynicism can be defined as being pessimist against change movements organizations carry out to reach success, not trusting to the leader making change and showing reaction to him/her, and attributing all fault related to failing in change to the lack of motivation and talent (Wanous et al. 2000:135).

While the phenomenon cynicism is used to explain the negative attitudes and behaviors the persons individually show against organization, that these behaviors are also seen in the other employee's means that a transition begins from individual cynicism to organizational cynicism. Organizational cynicism is a term used to account for the negative attitudes the employees feel against workplace from cognitive, emotional, and behavioral point of view (Fettahlıŏlu, 2015:181).

Although many definitions are made related to organizational cynicism, one of the most commonly used definitions is the definition made by Dean et al. (1998). According to Dean et al. (1998), the concept organizational cynicism is defined as negative attitudes the employee develops against organization it employs him/her and these attitudes are considered in three dimensions (Dean et al., 1998:345).

According to the dimension cognition of organizational cynicism, the individuals having cynic attitude have certain aims. According to this, organizations are devoid of a sound understanding of organizational principles and official rules are not taken into consideration by employees. There are no criteria such as honesty, sincerity, and justice. The relationships are made depending on the individual interests and the other employees in organization are not trusted (Balıkçıŏlu, 2013:23).

Emotional dimension is the second one of organizational cynicism. The emotional dimension of organizational cynicism includes strong emotional reactions such as disrespect, anger, and embarrassment (Yüksel, 2015:16). For example, cynics may feel furor and anger against the organization they work in and distain their organizations (Ahmadi, 2014:25).

According to behavioral dimension, the individuals having cynic attitudes make pessimist predictions about the future events in organization. They can make actions that are negative and mostly toward insulting people (Kalağan, 2009:48). In this dimension, employees use humor and especially sarcastic humor. Thus, individuals can mock through their cynic attitudes with the aims of organizations, write again job definitions, and make insulting comments (Bedük et al., 2015:21).

In the studies carried out, it was seen that there were many different elements leading to organizational cynicism. We can count the wrongly managed change efforts as the burden of excessive stress and role, not meeting the personal and organizational expectations, inadequate social support, upgrade at inadequate level compared to competitive level, aim confliction, increasing organizational complexity, inadequate level of being effective in making decision, lack of communication, psychological violations of contract, and dismissal as elements leading to cynicism (Yildiz, 2013:857)

As a result of organizational cynicism, both organizational commitments, thrusts, and justice perceptions of employees and the efficiency and effectiveness of organization decrease. In order to manage the phenomenon appearing in organization, it is necessary to apply some effective strategies. Toward preventing organizational cynicism from reaching high levels, it will be useful to use the instruments such as a transparent, clear, and accountable managerial understanding; support programs toward employees for them to be able to provide balance between their jobs and private lives due to their increasingly growing responsibilities and work intensities; and ethical codes to form trust to management (Tokgöz and Yllmaz, 2008:302). 
Bedük, A., Eryeşil, K., \& Duran Altınışık, G. (2017). The relationship between mobbing and organizational cynicism: An empirical study. Journal of Human Sciences, 14(4), 3167-3176. doi:10.14687/jhs.v14i3.4805

\section{Research Methodology}

\subsection{Research Subject, Objective and Matter}

The concept mobbing, the first of our variables, shortly, is attacks applied to sufferer by employer or other employees or incorporating unbalanced power. Organizational cynicism, the second variable, is a concept consisting of unbelief of individual against the organization he/she works in and integrity of organization, negative affection, critical view, and appreciations. The relationship and direction between these two negative concepts will be examined.

The aim of this study is to examine the relationship between mobbing, negatively evaluated for organizations, and organizational cynicism in its all dimensions and identify the direction of this relationship. Thus, it is also to shed light to the people, who are the most important entities of vocational high schools, and both managers and employees, to increase their awareness, and then provide them to make contribution to their struggles against mobbing and cynicism, evaluating the emerging results.

When the importance of our study is considered, mobbing and cynicism represent negative concepts. For organizations to survive and reach their aims, first of all, it is necessary to unsuccessfully carry out the struggle against negativities. On this subject, besides recognizing concepts in organizations and comparison of them in application, we consider that our study like many other studies brings the different perspective is also important.

\subsection{Research Methods}

In this study, an empirical study method was applied and survey method was used. The scales whose validities and reliabilities were proved were utilized. Our survey consists of two sections. The first section includes personal data introducing the demographic features of those participating in the study and the second section, the expressions of mobbing scale and cynicism scale.

"Mobbing Scale" with 29 expressions in the second section was derived from the study by Özalp (2013), which utilizes Psychological Terror Chart by Leymann and "Cynicism Scale" with 14 expressions, from the study by Çetinkaya (2014), which utilizes Organizational Cynicism Scale by Barandes. Organizational Cynicism Scale includes 3 dimensions in the form of that its first 5 expressions of consist of cognition cynicism; following 6 expressions, of emotional cynicism, and the last 3 expression, of behavioral cynicism. A total of 43 expressions present in both expressions are formed from 5 -point Likert Scale put in order as " $1=$ never" and " $5=$ always". Cronbach alpha values of the scales are "Mobbing $\alpha=0.914$ ", "Cognitive Cynicism $\alpha$ " $=0.946-\alpha$, "Emotional Cynicism $\alpha=0.907$ ", and "Behavioral Cynicism $\alpha=0.909$ " and, according to these results, it was seen that the reliability in the scale was provided. In order to be able to test the reliability of the scale, explanatory factor analyses were made. The data obtained as a result of the study were analyzed by using SPSS package program.

\subsection{Theoretical Model and Hypotheses}

In organizational meaning, is mobbing affect cynicism? In theory, three are various definitions regarding the subjects mobbing and cynicism. In the study, we carried out, whether mobbing or cynicism, although the relationships of these concepts are examined with the other variables, there are a few number of studies examining the relationship mobbing-cynicism.

$\mathrm{H}_{1}$ :There is a positive directional relationship between mobbing and organizational cynicism.

$\mathrm{H}_{2}$ : There is a positive directional relationship between mobbing and cognitive cynicism.

$\mathrm{H}_{3}$ :There is a positive directional relationship between mobbing and emotional cynicism.

$\mathrm{H}_{4}$ :There is a positive directional relationship between mobbing and behavioral cynicism.

In our country, mobbing and its effect on organizational commitment were examined (Karcığlu and Çelik, 2012) and according to the study results, it was identified that there was an opposite directional relationship between mobbing and organizational commitment. In health 
Bedük, A., Eryeşil, K., \& Duran Altınışık, G. (2017). The relationship between mobbing and organizational cynicism: An empirical study. Joumal of Human Sciences, 14(4), 3167-3176. doi:10.14687/jhs.v14i3.4805

sector, the examination of the relationship between ethical climate and mobbing behaviors was carried out by Şahin and Dündar (2011) and consequently, that facing with the various mobbing cases does not have any significant relationship with assessing ethical climate of workplace took place among identifications. The validity and reliability of the scale organizational cynicism developed by Brandes et al. (1999) in Kayseri Organized Industrial Zone was examined for Turkish employees. In general, the results obtained reveal that Turkish form of the scale "organizational cynicism" shows parallelism with original form. By means of adaptation study, it was identified that it was valid and reliable in sufficient rate (Karacaoğlu and Ince, 2012). We, setting out from the examples specified in our study and taking place in the literature, have also decided to examine the relationship of mobbing and cynicism.

\section{Findings}

The universe of this research is composed of the faculty members and lecturers of the four vocational high schools which are affiliated to Konya Selcuk University center. Since there will be difficulties in reaching the universe, sample was chosen by random sampling method which will represent the determined universe. In this context, the sample of the research was 121 faculty members and lecturers working at four vocational high schools affiliated to Konya Selcuk University center; but from 121 questionnaires, 71 (58.6\%) of them returned.

When the data were evaluated, it was identified that $43.7 \%$ of participants are female and $56.3 \%$ of then were male in terms of gender; that they were in the range of ages $31-41$ in the rate of $39.4 \%$; that they had an educational level at post graduate level in the rate of $54.9 \%$; that $69 \%$ of them were married; that they had monthly income of TL $2500-3500$ and TL over 4501 in the rate of $16.9 \%$; and that their length of service in institute was $1-5$ years in the rate of $31 \%$.

In order to be able to test the validity of the scales used in the study, explanatory factor analysis was made. The results of Kaiser Meyer Olkin (KMO) and Barlett Globalism Test obtained in the scope of this analysis are shown in Table I and Table II for both scales.

Tablo I. Explanatory Factor Analysis for Mobbing Scale

\begin{tabular}{|c|l|c|}
\hline \multicolumn{2}{|c|}{} & Mobbing Scale \\
\hline \multicolumn{2}{|c|}{ Kaiser Meyer Olkin Sample Sufficiency Test } & 0,650 \\
\hline \multirow{3}{*}{ Bartlett Globality Test } & Approximately Ki-square ( $\left.{ }^{2} 2\right)$ & 1495,252 \\
\cline { 2 - 3 } & Degree of Freedom (df) & 406 \\
\cline { 2 - 3 } & P & 0,000 \\
\hline
\end{tabular}

When Table 1 is examined, KMO value of Mobbing scale used in the study was found 0.650. Since this rate is above 0.6 that is acceptable rate, we can say that there is sample adequacy for this study. In addition, as a result of Bartlett test, $\mathrm{p}$ value turned out as 0.000 . This also shows that correlation matrix is not equal to unit matrix. That is, it shows compliance to factor analysis.

Tablo II. Explanatory Factor Analysis for the Organizational Cynicism Scale

\begin{tabular}{|l|l|l|}
\hline \multicolumn{2}{|c|}{} & $\begin{array}{l}\text { Organizational Cynicism } \\
\text { Scale }\end{array}$ \\
\hline \multicolumn{2}{|c|}{ Kaiser Meyer Olkin Sample Sufficiency Test } & 0,905 \\
\hline \multirow{3}{*}{ Bartlett Globality Test } & Approximately Ki-square (x2) & 1051,763 \\
\cline { 2 - 3 } & Degree of Freedom (df) & 91 \\
\cline { 2 - 3 } & P & 0,000 \\
\hline
\end{tabular}

When Table II is examined, KMO value of cynicism scale was identified as 0.905 . This rate shows that it is analyzed on an adequate sample. In addition, result of Bartlett test supports that correlation matrix does not equal to unit matrix with 0.000 that is, it shows compliance to factor analysis. 
Bedük, A., Eryeşil, K., \& Duran Altınışık, G. (2017). The relationship between mobbing and organizational cynicism: An empirical study. Joumal of Human Sciences, 14(4), 3167-3176. doi:10.14687/jhs.v14i3.4805

In order to be able to examine the reliability level of the survey, Cronbach Alpha values of the scales were examined. These values are shown in Table III.

Tablo III. Cronbach Alpha Values of Scales

\begin{tabular}{|l|c|c|}
\hline \multicolumn{1}{|c|}{ Scales } & $\begin{array}{c}\text { Number of } \\
\text { Questions }\end{array}$ & Cronbach Alfa \\
\hline Mobbing & 29 & 0,914 \\
\hline Cognitive Cynicism & 5 & 0,946 \\
\hline Emotional Cynicism & 6 & 0,907 \\
\hline Behavioral Cynicism & 3 & 0,909 \\
\hline
\end{tabular}

When Cronbach alpha values are examined, it was seen that the dimensions of organizational cynicism consisting of 14 questions and 3 factors were between 0.906-0.946, while mobbing scale had a Cronbach alpha value of 0.914 . These rates are highly above 0.70 that is acceptable rate. This shows the reliability of survey.

Tablo IV. Mean, Standard Deviation and Correlation Findings of Variables

\begin{tabular}{|l|c|c|c|c|c|c|}
\hline \multicolumn{1}{|c|}{ Scales } & Mean & $\begin{array}{l}\text { Standard } \\
\text { Deviation }\end{array}$ & Mobbing & $\begin{array}{l}\text { Cognitive } \\
\text { Cynicism }\end{array}$ & $\begin{array}{l}\text { Emotional } \\
\text { Cynicism }\end{array}$ & $\begin{array}{l}\text { Behavioral } \\
\text { Cynicism }\end{array}$ \\
\hline Mobbing & 1,3162 & 0,3583 & 1 & & & \\
\hline $\begin{array}{l}\text { Cognitive } \\
\text { Cynicism }\end{array}$ & 1,9099 & 1,07 & $\mathbf{0 , 7 9 8 *}$ & 1 & & \\
\hline $\begin{array}{l}\text { Emotional } \\
\text { Cynicism }\end{array}$ & 1,7887 & 1,0347 & $\mathbf{0 , 7 4 6 *}$ & $0,865^{*}$ & $0,734^{*}$ & 1 \\
\hline $\begin{array}{l}\text { Behavioral } \\
\text { Cynicism }\end{array}$ & 2,1831 & 1,098 & $\mathbf{0 , 5 4 0 *}$ & $0,721^{*}$ & & \\
\hline $\begin{array}{l}\text { Organization } \\
\text { al Cynicism }\end{array}$ & 1,9606 & 0,9832 & $\mathbf{0 , 7 5 2 *}$ & & & \\
\hline
\end{tabular}

${ }^{*} \mathrm{p}<0,001$

When Table IV is examined, it is seen that average mobbing level of the employees are 1.32; that average cognition cynicism is 1.92; average emotional cynicism is 1.79; and average behavioral cynicism is 2.18. The mean value regarding the perception of employees on organizational cynicism was identified as 1.96. These data show that mobbing perception is low in the sample, in which the study was carried out and that cynicism perception is low at the level of all factors.

In addition, in the study, organizational cynicism level was considered as a whole not on the basis of factors. In order to be able to test $\mathrm{H}_{1}$ hypothesis, the correlation between two scales was also examined and shown in the last lines in Table IV.

Examining correlation values between factors shown in Table 4, hypothesis tests were carried out. When the results are examined, it is seen that the relationship between mobbing and organizational cynicism is at the level of $75.2 \%$. When regarded to the relationships between mobbing and dimensions of organizational cynicism, it is seen that the highest relationship is with the cognitive dimension $(r=0.798)$; that this is followed by emotional cynicism $(r=0.746)$; and that the lowest relationship is with behavioral dimension $(\mathrm{r}=0.540)$. However, when a general evaluation is made, it can be said that there is a statistically significant and positive at high level between mobbing and cognitive cynicism and all of its dimensions. In this direction, hypotheses formed in the methodology part of the study and results of hypotheses are shown in Table 5. 
Bedük, A., Eryeşil, K., \& Duran Altınışık, G. (2017). The relationship between mobbing and organizational cynicism: An empirical study. Journal of Human Sciences, 14(4), 3167-3176. doi:10.14687/jhs.v14i3.4805

Tablo V. Hypothesis Testing Result Table

\begin{tabular}{|l|l|}
\hline \multicolumn{1}{|c|}{ Hypothesis } & Result \\
\hline $\begin{array}{l}\mathrm{H}_{1}: \text { There is a positive directional relationship between mobbing and organizational } \\
\text { cynicism }\end{array}$ & ACCEPT \\
\hline $\begin{array}{l}\mathrm{H}_{2:} \text { There is a positive directional relationship between mobbing and cognitive } \\
\text { cynicism. }\end{array}$ & ACCEPT \\
\hline $\begin{array}{l}\mathrm{H}_{3}: \text { There is a positive directional relationship between mobbing and emotional } \\
\text { cynicism. }\end{array}$ & ACCEPT \\
\hline $\begin{array}{l}\mathrm{H}_{4}: \text { There is a positive directional relationship between mobbing and behavioral } \\
\text { cynicism. }\end{array}$ & ACCEPT \\
\hline
\end{tabular}

\section{Conclusion}

As in every place of the world, the relationship between the concept mobbing, which is also often seen in Turkey but increases its bringing to light in the recent year, and cynicism, which expresses negative attitude against organization was studied in some vocational high schools of Selcuk University.

As a conclusion of the study, a significant and high level positive relationship was found between mobbing and organizational cynicism and the cognitive, emotional, and behavioral dimensions of cynicism. The academic members and teaching assistants feeling mobbing perception experience negativity against their organizations in the cognitive and emotional meaning and cast these to their behaviors.

In the study, carried out by Gül ve Ağıröz (2011) in health sector on 103 employees, a significant positive directional relationship was found between mobbing and organizational cynicism. However, any relationship was not found between mobbing and cognitive and behavioral organizational cynicism. In a study, carried out by Kalay and Oğrak (2012), on 240 participants in university sector taking place in service sector, similar results were identified and, according to correlation analysis, it was concluded that there was a positive directional and medium level relationship between mobbing and organizational cynicism. In the study carried out by Ayduğan (2012) on 936 employees serving in tourism sector, it was concluded that there was a positive directional and strong level relationship between mobbing and organizational cynicism. It is observed that the conclusions of the studies carried out in this context show parallelism. When foreign literature is examined, any relationship was not met, which examines the relationship between mobbing and organizational cynicism.

Mobbing and organizational cynicism are the concepts representing negativities. When considered in terms of our study, in case that mobbing is applied in vocational high schools, it should be considered that it can lead to organizational cynicism in academic members and teaching members with its every dimension. Here, we can express the reasons for the emergence of organizational cynicism with its behavioral dimension in the form of that academic members and teaching assistant are conscious; that they do not remain silence in the face of events and; they are aware that they can use and prove their rights in the legal meaning

Since the sample of this study consists of the academic members and teaching assistants serving in 4 vocational high schools present in Selcuk University, the strength to generalize the study results remains weak. In terms of the future studies, the study can be carried out again with large samples. It is necessary to consider that the study is evaluated out through the data belonging to only a certain slice of time. Since this study was only carried out in 4 vocational high school of Selcuk University, it is useful to carry out similar studies in the different vocational high school and faculties of the universities present in the different provinces. In addition, since this study was carried out in a certain time limitations, when the questions whose answers are searched for and hypotheses, which are put forward, are considered, it can be said that it is a more convenient approach to realize a continuous study as the method of data collecting 
Bedük, A., Eryeşil, K., \& Duran Altınışık, G. (2017). The relationship between mobbing and organizational cynicism: An empirical study. Journal of Human Sciences, 14(4), 3167-3176. doi:10.14687/jhs.v14i3.4805

\section{References}

Abraham, R. (2000). Organizational Cynicism: Bases and Consequences, Genetic, Social, and General Psychology Monographs, 126(3), 269-292.

Ahmadi, F. (2014). Örgütsel Sinizmin Örgütsel Bağlllık Üzerindeki Etkisinin İncelenmesi: Atatürk Üniversitesi Çalışanları Üzerine Bir Araştırma. Yüksek Lisans Tezi. Atatürk Üniversitesi, Sosyal Bilimler Enstitüsü. Erzurum.

Altinöz, M.; Çöp, S.; Sığındı, T. (2011). Alg1lanan Örgütsel Bağll1ık Ve Örgütsel Sinizm İlişkisi: Ankara'daki Dört ve Beş Yıldızlı Konaklama İşletmeleri Üzerine Bir Araştırma, S.Ü., Sosyal ve Ekonomik Araştırmalar Dergisi, 15(21), 285-316.

Anderson, L.M., Bateman T. (1997). Cynicism in the Workplace: Some Causes and Effects, Journal of Organizational Behavior, Vol: 18, 449-469.

Arslan, E. T. (2012). Süleyman Demirel Üniversitesi İktisadi Ve İdari Bilimler Fakültesi Akademik Personelinin Genel ve Örgütsel Sinizm Düzeyi. Doğuș Üniversitesi Dergisi,, 13(1), 13-14.

Ayduğan, Nil (2012). Mobbingin Örgütsel Sinizme Etkisi: Beş Yıldızlı Otel İşletmelerinde Bir Uygulama. Afyon Kocatepe Üniversitesi, Sosyal Bilimler Enstitüsü, Turizm İşletmeciliği Ve Otelcilik Anabilim Dal, Yüksek Lisans Tezi.

Balikçioğlu, S. (2013). Antalya Bölgesi Konaklama İşletmeleri Çalışanlarının Örgütsel Sinizm Tutumları İle Bağlllık İlişkisi Üzerine Bir Araştırma. Yüksek Lisans Tezi, Mustafa Kemal Üniversitesi, Sosyal Bilimler Enstitüsü, Hatay.

Baş, N., ve Oral, E. T. (2012). Mobbing Davranış1 Ve Kişilik Özellikleriyle İlişkisi. İstanbul Ticaret Üniversitesi Sosyal Bilimler Dergisi, Yul:11(21), 12.

BEDÜK, A., Cakıcı, A. B., ve Çiçekdağı, H. İ. (2015). An Organızatıonal Evaluatıon On Cynıcısm And Organizational Commitment: Example Of Disaster And Emergency Employees. Int.J.Eco. Res., v6i2, 18-31 ISSN: 2229-6158.

Çetin, C. ve Bağcı Kurt, N. (2014). Mobbing ve Çalışan Sağlığı. Toplum ve Sosyal Hiæ̌met Dergisi, 25(2), 113.

Çetinkaya, F. F. (2014). Hizmet İşletmelerinde Psikolojik Sözleşme İhlalleri Ve Örgütsel Sinizm İlişkisi: Kapadokya Bölgesİ 4 Ve 5 Yıldızlı Otel İşletmelerinde Bir Araştırma (Doktora Tezi), Kocatepe Üniversitesi, Afyonkarahisar. (372441)

Davenport, Noa., Ruth Distler Schwartz, Gail Pursell Elliott (2003). Mobbing. Sistem Yayıncllk, İstanbul.

Dean, J., Brande, P. and Dharwadkar, R. (1998). Organizational Cynicism, Academy of Management Review, 23(2), 341-352.

Erdoğan, P. ve Bedük, A. (2013). Örgütsel Sinizm ile Örgütsel Vatandaşlık Davranışı Arasındaki İlisski; Sağlık Sektöründe Bir Araştırma. Sosyoteknik Sosyal ve Teknik Araştırmalar Dergisi, $3(6), 17-36$.

Fettahlioğlu, Ö. O. (2015). Günümüz İşletmelerinin Temel Hastalığı; Örgütsel Sinizme Yönelik Algılamaların, Tükenmişlik Boyutları Üzerine Etkisi. Akademik Sosyal Araştırmalar Dergisi, 3(13), 178-191.

Göktürk, G. Y. ve Bulut, S. (2012). Mobbing: İşyerinde Psikolojik Taciz. Abant İzęt Baysal Üniversitesi Sosyal Bilimler Enstitï̈ü Dergisi, 2012/1(24), 54.

Gül, H. ve Ağıröz, A. (2011). Mobbing ve Örgütsel Sinizm Arasındaki ilişkiler: Hemşireler Üzerinde Bir Uygulama. Afyan Kocatepe Üniversitesi İ̈BF Dergisi, 13(2), 35.

Gül, H. ve Özcan, N. (2011). Mobbing Ve Örgütsel Sessizlik Arasındaki Ilişkiler: Karaman Il Özel Idaresinde Görgül Bir Çalısma. Kahramanmarass Sütçü Imam Üniversitesi İktisadi ve İdari Bilimler Fakïltesi Dergisi, 1(2), 108.

Kahya, C. (2013). Örgütsel Sinizm, İş Performansını Etkiler mi? İş Tatmininin Aracilık Etkisi. Küresel İktisat ve Ișletme Callsmalar Dergisi, 2(3), 35.

Kalağan, G. (2009). Araştırma Görevlilerinin Örgütsel Destek Alg1ları İle Örgütsel Sinizm Tutumları Arasındaki İlişki. Yüksek Lisans Tezi. Akdeniz Üniversitesi, Sosyal Bilimler Enstitüsü. Antalya. 
Bedük, A., Eryeșil, K., \& Duran Altınıșık, G. (2017). The relationship between mobbing and organizational cynicism: An empirical study. Journal of Human Sciences, 14(4), 3167-3176. doi:10.14687/jhs.v14i3.4805

Kalay, F. ve Oğrak, A. (2012). Örgütsel Sessizlik, Mobbing ve Örgütsel Sinizm ĠliĢkisi: Örnek Bir Uygulama, 20. Ulusal Yönetim ve Organizasyon Kongresi Bildiri Kitab1, '́Gzmir, (24 - 26 May1s), 492-496.

Karacaoğlu, K. ve İnce, F. (2012). Brandes, Dharwadkar ve Dean'in (1999) Örgütsel Sinizm Ölçeği Türkçe Formunun Geçerlilik ve Güvenilirlik Çalışması: Kayseri Organize Sanayi Bölgesi Örneği. Business and Economics Research Journal, 3(3), 88.

Karahan, A. ve Yılmaz, H. (2014). Mobbing ve Örgütsel Bağllık İlişkisine Yönelik Bir Çalışma. Journal of Yasar University, 9(33), 5695.

Karcioğlu, F. ve Çelik, Ü. H. (2012). Mobbing (Yıldırma) ve Örgütsel Bağllliğa Etkisi. Atatürk Üniversitesi İktisadi ve İdari Bilimler Dergisi, 26(1), 60.

Kiliç, Ş. (2011). İlköğretim Öğretmenlerinin Örgütsel Sinizm Ve Örgütsel Bağlllık Düzeyleri Arasındaki İlişki: Keçiören İlçesi Örneği. Yüksek Lisans Tezi, Hacettepe Üniversitesi, Sosyal Bilimler Enstitüsü, Ankara.

Leymann, Heinz (1996). The Content and Development of Mobbing at Work. Europen Journal Of Work And Organizational Psychology. Vol.5, No.2, 165-184

Mete, M., Ünal, Ö. F., Akyüz, B. ve Kılıç, R. (2015). Psikolojik Şiddetin İşe Baglı Tükenmişliğe Etkisi: Batman İlinde Öğretmenler Üzerine Bir Araştırma. Vişyoner Dergisi, 6(12), 39.

Moutner, T. (1997). Dictionary of Philosophy, Penguin Reference Books.

Özalp, F. (2013). Çalssma Yaşaminda Mobbing Ve İș Tatmini Arasındaki İliskki; Kamu Kurulusunda Bir Uygulama (Yüksek Lisans), Aydın Üniversitesi, İstanbul. (349142)

Polat, O. ve Pakiş, I. (2012). Mobbing: İşyerinde Psikolojik Taciz. Acıbadem Üniversitesi Sağhık Bilimleri Dergisi, 3(4), 212.

Rayner, Charlotte ve Hoel, Helge (1997). A Summay Review of Literatüre Relating To Workplace Bullying. Journal Of Community And Applied Social Psychological. Vol.7, 181-191

Shea, L.,(2009). The Cynic Enlightenment Diogenes in the Salon, The Johns Hopkins University Press, Baltimore, Maryland.

Solmuş, T. (2005). "İş yaşamında Travmalar: Cinsel Taciz ve Duygusal Zorbalık/Taciz (Mobbing)", İş-Güç Endüstri İlişkileri ve İnsan Kaynakları Dergisi, C. 7, S. 2, Haziran, 2.

Şahin, B. ve Dündar, T. (2011). Sağlık Sektöründe Etik İklim Ve Yıldırma (Mobbing) Davranışları Arasındaki İlişkinin İncelenmesi. Ankara Üniversitesi SBF Dergisi, 66(01), 155.

Tokgöz, N. ve Yılmaz, H. (2008). Örgütsel Sinizm: Eskişehir Ve Alanya’daki Otel Işletmelerinde Bir Uygulama. Anadolu Universitesi Sosyal Bilimler Dergisi, 8(2), 302.

Wanous, J. P.,Reichers, A. E., ve Austin, J. T. (2000). Cynicism About Organizational Change; Measurement, Antecedents, And Correlates. Group\&Organization Management, 25(2), 132-153.

Yildiz, K. (2013). Örgütsel Bağlilik Ile Örgütsel Sinizm Ve Örgütsel Muhalefet Arasindaki Ilişki. Turkish Studies - International Periodical for The Languages, Literature and History of Turkish or Turkic, 8(6), 857.

Yüksel, H. (2015). Örgütsel Sinizm ve Bağlllık Arasındaki İlişki: İlk ve Ortaokul Öğretmenleri Üzerinde Bir Araştırma. Yüksek Lisans Tezi. Dokuz Eylül Üniversitesi. Eğitim Bilimleri Enstitüsü. İzmir. 